\title{
Tillage system and lime application in a tropical region: Soil chemical fertility and corn yield in succession to degraded pastures
}

\author{
Carlos S. Tiritan ${ }^{\mathrm{a}}$, Leonardo T. Büll ${ }^{\mathrm{b}}$, Carlos A.C. Crusciol ${ }^{\mathrm{c}, *}$, Antonio C.A. Carmeis Filho ${ }^{\mathrm{c}}$, \\ Dirceu M. Fernandes ${ }^{\mathrm{b}}$, Adriano S. Nascente ${ }^{\mathrm{d}}$ \\ a University of Western São Paulo (UNOESTE). Raposo Tavares Highway, km 572, Campus II, Block B3. Zip Code 19067-175, Presidente Prudente, State of São \\ Paulo, Brazil \\ ${ }^{\mathrm{b}}$ São Paulo State University (UNESP), College of Agricultural Sciences (FCA), Department of Soil and Environmental Resources, Lageado Experimental Farm, \\ Botucatu, State of São Paulo, Brazil \\ ${ }^{\mathrm{c}}$ UNESP, FCA, Dep. of Crop Science, Lageado Experimental Farm, Botucatu, State of São Paulo, Brazil \\ d Brazilian Agricultural Research Corporation (EMBRAPA), Rice and Beans Research Center, Santo Antonio de Goiás, State of Goiás, Brazil
}

\section{A R T I C L E I N F O}

\section{Keywords:}

No-tillage

Acidity

Soil management

Cation mobility

\begin{abstract}
A B S T R A C T
The chemical degradation of soils, due to acidity, and erosion processes, resulting from a traditional tillage system method, are one of the main factors responsible for decreasing the productive capacity of tropical pastures. Thus, establishing the crop-livestock integration system (CLIS) by applying lime on surface without disrupting the soil is interest. The objectives of this study were to evaluate the chemical changes in a soil following surface application or incorporation of lime and to determine the effects of liming on plant nutrition, corn (Zea mays L.) grain yields, and various yield components in cultivated areas of degraded Brachiaria decumbens Stapf pasture. A randomized block experimental design with a splitplot arrangement consisting of two management systems (tillage and no-tillage system) and three lime rates $\left(0.0 ; 2.7\right.$ and $\left.5.4 \mathrm{Mg} \mathrm{ha}^{-1}\right)$ was used. The highest reactivity of calcium carbonate was observed after

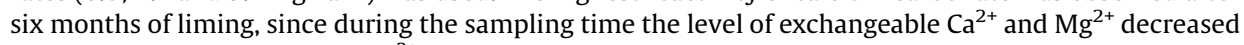
to $0.05 \mathrm{~m}$ depth, and increased $\mathrm{Al}^{3+}$ and soil acidity to $0.3 \mathrm{~m}$. The incorporation of lime did not increase the movement or reaction of the bases in the degraded soil profile. Therefore, surface liming under perennial forage crop residues ( $B$. decumbens Stapf. pasture) provided the best alternative to increase the soil $\mathrm{pH}$ index at a depth of up to $0.3 \mathrm{~m}$. Macronutrients uptake by plant, yield components, and corn grain yield were not affected by the application method. However, the use of limestone showed viability to maximize up to $20 \%$ in corn productivity, regardless of lime rate. The results suggest that it is possible to ameliorate soil acidity and chemical properties of degraded grassland only by surface application of limestone; however, the strategy is considered effective just for soils with no physical restriction to root development.
\end{abstract}

(C) 2015 Elsevier B.V. All rights reserved.

\section{Introduction}

Increasing worldwide consumption of meat, grains, fibers, and bioenergy has made it necessary to expand the productive capacity of agricultural lands, including those considered to have low fertility. Tropical soils are considered as major agricultural borders (Borlaug and Dowswell, 1998), since have favorable environmental factors for agricultural activity. Recently, the consolidation of CLIS in tropical regions, including the integration of annual crop

\footnotetext{
* Corresponding author.

E-mail addresses: tiritan@unoeste.br (C.S. Tiritan), bull@fca.unesp.br (L.T. Büll), crusciol@fca.unesp.br (C.A.C. Crusciol), tonycarmeis@hotmail.com (A.C.A. Carmeis Filho), dmfernandes@fca.unesp.br (D.M. Fernandes).
}

production (corn, soybeans, rice, cotton and sorghum) with meat and milk production (Carvalho et al., 2011; Loss et al., 2011; Mateus et al., 2011; Borghi et al., 2013; Crusciol et al., 2014), has confirmed the potentials of these productive soils.

It is estimated that the Brazilian cerrado region, which has native vegetation similar to that of African savannahs, could produce 250 million tons of grain and 12 million tons of meat annually (Lee et al., 2012). However, despite this high potential, approximately 50 million hectares of pasture in this region have been subjected to some level of degradation (Borghi et al., 2013). The naturally acidic conditions of tropical soils, which have been intensified by the use of nitrogenous fertilizers containing ammonia (Caires et al., 2015), have limited the agricultural potentials of these soils in many regions of the world. In most cases, the low chemical fertility of these degraded soils result from aluminum and manganese toxicity and low 
availability of exchangeable bases, such as calcium $\left(\mathrm{Ca}^{2+}\right)$ and magnesium $\left(\mathrm{Mg}^{2+}\right)$ (Oliveira and Pavan, 1996; Caires et al., 2005; Calegari et al., 2013).

Liming is one of the most common and effective practices for reducing or neutralizing the negative effects resulting from acidity. In addition, liming is important for increasing the availability of Ca and Mg in soils (Caires et al., 1998; Soratto and Crusciol, 2008; Joris et al., 2013). Due to its low solubility, lime is usually incorporated into the soil by conventional methods (plowing and harrowing). However, these proceedings drastically changes the soil physical properties, including the soil structure and porosity (Pöttker and Ben, 1998), which are often good where perennial forage species are cultivated. (Salton et al., 2008; Cavalieri et al., 2009, 2010).

In most grain-producing areas that use no-tillage systems, soil acidity correction has only been performed via surface liming (Conyers et al., 2003; Soratto and Crusciol, 2008; Briedis et al., 2012) because preserving the soil structure is extremely important for obtaining good root development and for reducing degradation processes, such as erosion. Despite the benefits of surface application, several studies have demonstrated that the speed of the limestone reaction is slower in the subsurface when the lime is not incorporated (Pöttker and Ben, 1998; Caires at al., 2008). Soratto and Crusciol (2008) presents contradictory results because they confirm that liming affects the subsurface layers after a relatively short period. However, these results are still discordant, and the viability of surface liming for recovering degraded pastures remains unknown.

The need for limestone in agricultural systems with minimal mobilization is smaller than that in conventional systems, with greater soil mobilization (Pöttker and Ben, 1998; Caires et al., 2000). This difference is attributed to the complexation of exchangeable $\mathrm{Al}$ by soil organic matter, which is an intense process within conservation systems and involves the accumulation of large amounts of organic matter (van Hees et al., 2000). Knowledge of changes in soil chemical attributes and their effects on grain yield are necessary for establishing and adjusting lime requirements in CLIS. However, in areas with no physical limitations, such as compaction or erosion, and where low pasture productivity exclusively results from reduced soil chemical fertility, it is likely that reducing soil acidity by adding lime to the surface can provide results that are comparable with those obtained when using conventional methods.

The objectives of this study were to evaluate the chemical changes in the soil that were affected by the surface application or incorporation of lime and to determine the effects of these methods on plant nutrition, yield components, and corn grain yield in a degraded Brachiaria decumbens Stapf pasture.

\section{Materials and methods}

\subsection{Site description}

This experiment was performed in Botucatu City (in the State of São Paulo in southeastern Brazil; 48 $23^{\prime} \mathrm{W}, 22^{\circ} 51^{\prime} \mathrm{S}, 765 \mathrm{~m}$ above sea level) during two growing seasons. According to the Koppen classification system, the climate of the study area is Cwa, which is tropical with dry winters and hot and rainy summers (Lombardi and Drugowich, 1994). The rainfall and the mean maximum and minimum temperatures recorded during the experimental period are shown in Table 1 (Unicamp, 2012).

The soil is a sandy clay loam, kaolinitic, thermic Typic Haplorthox with 600, 208 and $192 \mathrm{~g} \mathrm{~kg}^{-1}$ of clay, silt and sand, respectively. In our study, the soil was managed using conventional tillage (one disk plow with a working depth of $200 \mathrm{~mm}$ and two leveling harrows with a working depth of $100 \mathrm{~mm}$ ) for five or more years before the trial began. The area was cultivated following its use as a Brachiaria decumbens Stapf. pasture without soil mobility.

Before starting the experiment, the soil chemical characteristics were determined at depths of $0-0.05,0.05-0.10,0.10-0.20$, and $0.20-0.30 \mathrm{~m}$ (Table 2). These initial values were only used for comparison with the following results and were not considered in the statistical analysis. The soil $\mathrm{pH}$ was determined in $0.01 \mathrm{~mol} \mathrm{~L}^{-1}$ $\mathrm{CaCl}_{2}$ (1:2.5 soil/solution ratio). Exchangeable $\mathrm{Al}$ was extracted using neutral $1 \mathrm{~mol} \mathrm{~L}^{-1} \mathrm{KCl}$ with a 1:10 soil/solution ratio and determined by titration in $0.025 \mathrm{~mol} \mathrm{~L}^{-1} \mathrm{NaOH}$ (Yuan, 1959). The soil organic matter content was evaluated using the Walkley-Black method (Walkley and Black, 1934). Exchangeable basic cations $\left(\mathrm{Ca}^{2}\right.$ ${ }^{+}, \mathrm{Mg}^{2+}$, and $\mathrm{K}^{+}$) and available $\mathrm{P}$ were extracted using an ionic resin (van Raij et al., 1986). Exchangeable $\mathrm{Ca}^{2+}, \mathrm{Mg}^{2+}$ and $\mathrm{K}^{+}$were determined using a Shimadzu AA-6300 atomic absorption/FlameEmission spectrophotometer. Phosphorus was determined colorimetrically (Murphy and Riley, 1962), using a FEMTO 600S spectrophotometer. Base saturation values were calculated using

Table 2

Chemical characteristics of the soil before the experiment.

\begin{tabular}{|c|c|c|c|c|c|c|c|c|c|}
\hline $\begin{array}{l}\text { Depth } \\
\mathrm{m}\end{array}$ & $\mathrm{pH}\left(\mathrm{CaCl}_{2}\right)$ & $\begin{array}{l}\mathrm{SOM} \\
\mathrm{g} \mathrm{dm}^{-3}\end{array}$ & $\begin{array}{l}\mathrm{P}(\text { resin }) \\
\mathrm{mg} \mathrm{dm}^{-3}\end{array}$ & $\mathrm{Al}^{3+}$ & $\begin{array}{r}\mathrm{H}+\mathrm{Al} \\
\mathrm{mn}\end{array}$ & $\begin{array}{c}\mathrm{Ca}^{2+} \\
\operatorname{lol}_{\mathrm{c}} \mathrm{dn}\end{array}$ & $\mathrm{Mg}^{2+}$ & $\mathrm{K}^{+}$ & $\begin{array}{l}\text { BS } \\
\%\end{array}$ \\
\hline $0.00-0.05$ & 3.9 & 31 & 13 & 27 & 62 & 7.7 & 5.8 & 0.8 & 19 \\
\hline $0.05-0.10$ & 3.8 & 30 & 8 & 30 & 67 & 5.5 & 5.0 & 1.0 & 15 \\
\hline $0.10-0.20$ & 3.7 & 27 & 10 & 33 & 90 & 4.7 & 4.1 & 0.5 & 9 \\
\hline $0.20-0.30$ & 3.6 & 25 & 4 & 36 & 85 & 2.1 & 2.0 & 0.2 & 5 \\
\hline $0.00-0.20$ & 3.8 & 30 & 10 & 30 & 70 & 6.2 & 5.1 & 0.8 & 15 \\
\hline
\end{tabular}

Table 1

Rainfall, maximum and minimum temperatures at Botucatu, São Paulo State, Brazil, during the study period and long-term average.

\begin{tabular}{|c|c|c|c|c|c|c|c|c|c|}
\hline \multirow[t]{2}{*}{ Climate characteristics } & \multicolumn{9}{|c|}{ Month } \\
\hline & Sep & Oct & Nov & Dec. & Jan. & Feb. & Mar. & Apr. & May \\
\hline \multicolumn{10}{|l|}{ First season } \\
\hline Monthly rain, $\mathrm{mm}$ & 90.4 & 133.9 & 146.3 & 290.3 & 400.1 & 203.5 & 111.0 & 70.3 & 44.8 \\
\hline Mean max. temp., ${ }^{\circ} \mathrm{C}$ & 25.3 & 27.1 & 27.8 & 28.0 & 27.9 & 28.3 & 28.4 & 25.8 & 22.8 \\
\hline Mean min. temp., ${ }^{\circ} \mathrm{C}$ & 13.7 & 14.9 & 15.3 & 18.9 & 20.0 & 19.8 & 19.3 & 16.1 & 13.4 \\
\hline \multicolumn{10}{|l|}{ Second season } \\
\hline Monthly rain, mm & - & - & - & 183.8 & 220.7 & 227.9 & 162.4 & 12.1 & 10.3 \\
\hline Mean max. temp., ${ }^{\circ} \mathrm{C}$ & - & - & - & 28.9 & 27.8 & 27.4 & 27.0 & 27.1 & 24.4 \\
\hline Mean min. temp., ${ }^{\circ} \mathrm{C}$ & - & - & - & 18.7 & 19.1 & 19.0 & 18.6 & 17.0 & 14.1 \\
\hline \multicolumn{10}{|l|}{ Long-term (50-yr) avg. } \\
\hline Monthly rain, mm & 71.3 & 126.5 & 133.3 & 184.6 & 224.0 & 203.2 & 140.9 & 66.5 & 75.8 \\
\hline Mean max. temp., ${ }^{\circ} \mathrm{C}$ & 26.2 & 26.7 & 27.2 & 27.2 & 28.1 & 28.0 & 28.0 & 27.0 & 24.0 \\
\hline Mean min. temp., ${ }^{\circ} \mathrm{C}$ & 12.4 & 14.2 & 15.1 & 16.4 & 17.1 & 17.4 & 19.0 & 17.0 & 15.0 \\
\hline
\end{tabular}


the exchangeable bases and total acidity results at $\mathrm{pH} 7.0(\mathrm{H}+\mathrm{Al})$ (van Raij et al., 2001).

\subsection{Experimental design and treatments}

A randomized block experimental design was used with a split plot scheme and four replications. The treatments consisted of the following two management systems: (1) conventional tillagelime was incorporated in one pass using a disk plow and two passes using a leveling harrow and (2) no-tillage-lime was applied on the soil surface without incorporation. In addition, the following three dolomitic limestone rates were used: (1) $0.0 \mathrm{Mg} \mathrm{ha}^{-1}$ (no liming), (2) $2.7 \mathrm{Mg} \mathrm{ha}^{-1}$, and (3) $5.4 \mathrm{Mg} \mathrm{ha}^{-1}$. Greater liming rates were calculated to achieve a base saturation of 70\% (van Raij et al., 1997). The dolomitic limestone composition consisted of $30 \% \mathrm{Ca}$ and $7.2 \%$ $\mathrm{Mg}$, with an effective calcium carbonate equivalence (ECCE) of $82 \%$.
The main plots were $150 \mathrm{~m}^{2}(5 \times 30 \mathrm{~m})$, with sub plots of $50 \mathrm{~m}^{2}$ $(5 \times 10 \mathrm{~m})$. Each sub plot consisted of five $10-\mathrm{m}$ long corn rows that were spaced at $0.9 \mathrm{~m}$. Data samples were collected in three central rows, which were $1 \mathrm{~m}$ from the end of each plant row. Two external rows surrounded the central rows.

\subsection{Liming application}

Lime was manually applied uniformly on the soil surface at the beginning of the rainy season (September) during the first year of the experiment. The next day, incorporation was conducted in the plots with conventional tillage. Incorporation was performed using a Massey Ferguson 299 with 6 cylinders and $130 \mathrm{hp}$. The following implements were used: a) BALDAN ${ }^{(\mathrm{r})}$ AFL Mounted Disc Plough with 4 discs (30" diameter), a working width of $1200 \mathrm{~mm}$, and a working depth of $200 \mathrm{~mm}$ and b) a BALDAN ${ }^{(\mathrm{r})}$ NVCR remote Control

Table 3

ANOVA significance for soil chemical attributes.

\begin{tabular}{|c|c|c|c|c|c|c|c|c|}
\hline $\begin{array}{l}\text { Depth } \\
(\mathrm{m})\end{array}$ & Blocks & System (S) & Rates (R) & Time sampling (TS) & $\mathrm{S} \times \mathrm{R}$ & $\mathrm{S} \times \mathrm{TS}$ & $\mathrm{R} \times \mathrm{TS}$ & $\mathrm{S} \times \mathrm{R} \times \mathrm{TS}$ \\
\hline \multicolumn{9}{|l|}{$\mathrm{pH}$} \\
\hline $0-0.05$ & 0.4783 & 0.8439 & $<0.0001$ & $<0.0001$ & 0.7623 & 0.4493 & 0.5734 & 0.7482 \\
\hline $0.05-0.10$ & 0.6392 & 0.8832 & 0.0007 & $<0.0001$ & 0.7238 & 0.6673 & 0.7739 & 0.8287 \\
\hline $0.10-0.20$ & 0.7492 & 0.9804 & 0.0012 & $<0.0001$ & 0.4899 & 0.4373 & 0.6225 & 0.6399 \\
\hline $0.20-0.30$ & 0.5298 & 0.9268 & $<0.0001$ & 0.0071 & 0.5381 & 0.5389 & 0.5298 & 0.7464 \\
\hline \multicolumn{9}{|l|}{$\mathrm{H}+\mathrm{Al}$} \\
\hline $0-0.05$ & 0.7392 & 0.9777 & $<0.0001$ & $<0.0001$ & 0.5391 & 0.5483 & 0.5638 & 0.6299 \\
\hline $0.05-0.10$ & 0.2648 & 0.9853 & 0.0022 & $<0.0001$ & 0.3529 & 0.4542 & 0.7333 & 0.7109 \\
\hline $0.10-0.20$ & 0.4683 & 0.9942 & $<0.0001$ & 0.0302 & 0.6539 & 0.6571 & 0.6313 & 0.8321 \\
\hline $0.20-0.30$ & 0.6184 & 0.9978 & 0.0149 & 0.0156 & 0.5211 & 0.7299 & 0.5831 & 0.6778 \\
\hline \multicolumn{9}{|c|}{ Exchangeable $\mathrm{Al}^{3+}$} \\
\hline $0-0.05$ & 0.3849 & 0.9752 & $<0.0001$ & $<0.0001$ & 0.6830 & 0.3382 & 0.5511 & 0.8833 \\
\hline $0.05-0.10$ & 0.2395 & 0.9872 & $<0.0001$ & $<0.0001$ & 0.7382 & 0.4366 & 0.4121 & 0.8492 \\
\hline $0.10-0.20$ & 0.5639 & 0.9722 & $<0.0001$ & $<0.0001$ & 0.5930 & 0.7441 & 0.5391 & 0.6976 \\
\hline $0.20-0.30$ & 0.4693 & 0.9699 & 0.0022 & $<0.0001$ & 0.6349 & 0.6111 & 0.5830 & 0.7087 \\
\hline \multicolumn{9}{|c|}{ Soil organic matter } \\
\hline $0-0.05$ & 0.5483 & 0.9735 & 0.3781 & 0.4384 & 0.7322 & 0.8383 & 0.7868 & 0.7999 \\
\hline $0.05-0.10$ & 0.4729 & 0.9682 & 0.5011 & 0.2579 & 0.7644 & 0.7492 & 0.6745 & 0.8842 \\
\hline $0.10-0.20$ & 0.5582 & 0.9750 & 0.3897 & 0.5771 & 0.5328 & 0.7960 & 0.7253 & 0.7483 \\
\hline $0.20-0.30$ & 0.4439 & 0.7436 & 0.2971 & 0.6382 & 0.4499 & 0.6988 & 0.6288 & 0.9672 \\
\hline \multicolumn{9}{|c|}{ Phosphorus } \\
\hline $0-0.05$ & 0.5438 & 0.9362 & 0.0079 & 0.2461 & 0.4682 & 0.5594 & 0.5789 & 0.9055 \\
\hline $0.05-0.10$ & 0.4724 & 0.9514 & 0.0033 & 0.5188 & 0.6381 & 0.4493 & 0.6940 & 0.8656 \\
\hline $0.10-0.20$ & 0.5922 & 0.8853 & 0.4670 & 0.2393 & 0.5932 & 0.6583 & 0.7422 & 0.7581 \\
\hline $0.20-0.30$ & 0.5290 & 0.9804 & 0.6825 & 0.3366 & 0.7392 & 0.8481 & 0.8131 & 0.8939 \\
\hline \multicolumn{9}{|c|}{ Exchangeable $\mathrm{Ca}^{2+}$} \\
\hline $0-0.05$ & 0.3438 & 0.9924 & $<0.0001$ & $<0.0001$ & 0.4382 & 0.4829 & 0.5392 & 0.6473 \\
\hline $0.05-0.10$ & 0.5325 & 0.9851 & $<0.0001$ & 0.7468 & 0.3842 & 0.5730 & 0.6171 & 0.7488 \\
\hline $0.10-0.20$ & 0.4280 & 0.9196 & 0.0244 & 0.6142 & 0.5291 & 0.6788 & 0.6444 & 0.6961 \\
\hline $0.20-0.30$ & 0.4655 & 0.9823 & 0.0099 & 0.8677 & 0.6466 & 0.7573 & 0.5780 & 0.7107 \\
\hline \multicolumn{9}{|c|}{ Exchangeable $\mathrm{Mg}^{2+}$} \\
\hline $0-0.05$ & 0.7432 & 0.9684 & $<0.0001$ & $<0.0001$ & 0.4482 & 0.5392 & 0.5390 & 0.6675 \\
\hline $0.05-0.10$ & 0.6489 & 0.9842 & $<0.0001$ & $<0.0001$ & 0.5729 & 0.8493 & 0.5777 & 0.8767 \\
\hline $0.10-0.20$ & 0.7745 & 0.9467 & $<0.0001$ & $<0.0001$ & 0.6201 & 0.6382 & 0.6506 & 0.7694 \\
\hline $0.20-0.30$ & 0.6533 & 0.9623 & $<0.0001$ & $<0.0001$ & 0.6822 & 0.5494 & 0.7218 & 0.5868 \\
\hline \multicolumn{9}{|c|}{ Exchangeable $\mathrm{K}^{+}$} \\
\hline $0-0.05$ & 0.5438 & 0.9743 & $<0.0001$ & $<0.0001$ & 0.5392 & 0.5784 & 0.6737 & 0.8953 \\
\hline $0.05-0.10$ & 0.8302 & 0.9438 & $<0.0001$ & $<0.0001$ & 0.6539 & 0.8464 & 0.5648 & 0.7769 \\
\hline $0.10-0.20$ & 0.4729 & 0.9576 & 0.0182 & 0.0189 & 0.7593 & 0.6667 & 0.6471 & 0.6201 \\
\hline $0.20-0.30$ & 0.3799 & 0.9051 & 0.0264 & 0.0101 & 0.6585 & 0.8541 & 0.5544 & 0.7858 \\
\hline \multicolumn{9}{|c|}{ Base saturation } \\
\hline $0-0.05$ & 0.3689 & 0.9911 & $<0.0001$ & $<0.0001$ & 0.4730 & 0.6121 & 0.4532 & 0.5778 \\
\hline $0.05-0.10$ & 0.2276 & 0.9935 & $<0.0001$ & $<0.0001$ & 0.4211 & 0.4212 & 0.5949 & 0.7656 \\
\hline $0.10-0.20$ & 0.4729 & 0.9928 & 0.0045 & $<0.0001$ & 0.6482 & 0.5762 & 0.6133 & 0.8539 \\
\hline $0.20-0.30$ & 0.8568 & 0.9897 & 0.0096 & $<0.0001$ & 0.5722 & 0.5498 & 0.4309 & 0.8022 \\
\hline
\end{tabular}


Leveling Harrow with 28 discs (20" diameter), a working width of $2350 \mathrm{~mm}$, and a working depth of $100 \mathrm{~mm}$. Corn (Zea mays L.) was sown approximately 3 months after lime application.

\subsection{Crop management}

During both growing seasons, corn was sown in the presence of fallow residue ( $6000 \mathrm{~kg} \mathrm{ha}^{-1}$ of dry matter on the soil surface) following a glyphosate application $\left(1800 \mathrm{~g} \mathrm{ha}^{-1}\right)$ with a volume of $250 \mathrm{Lha}^{-1} 20 \mathrm{~d}$ before sowing. Single-cross Pioneer hybrid (P30F90) was sown on December 22th (first year) and December 10th (second year) using a no-till drill to produce a population of 55,000 plants ha ${ }^{-1}$. Furrow opening, fertilizer distribution, and corn seeding were performed using a mechanical seeder (Semeato Model Personale Drill-13). Sowing mineral fertilization was performed according to the recommendations of Cantarella et al. (1997) for corn crops, resulting in the application of $25 \mathrm{~kg}$ $\mathrm{N}$ ha ${ }^{-1}$ as urea, $89.6 \mathrm{~kg}_{2} \mathrm{O}_{5} \mathrm{ha}^{-1}$ as triple superphosphate and $51.2 \mathrm{~kg} \mathrm{~K} \mathrm{~K}_{2} \mathrm{ha}^{-1}$ as potassium chloride. Mineral fertilization of $100 \mathrm{~kg} \mathrm{~N} \mathrm{ha}^{-1}$ as ammonium sulfate was performed by topdressing when the corn plants reached the stage with five expanded leaves (V5), according to the recommendations of Cantarella et al. (1997). Maize was cultivated according to the needs of the crop. All pesticides applications were performed using a tractor-mounted boom sprayer (Condor 600 M14 JACTO $^{(\mathrm{r})}$ ) with a $14 \mathrm{~m}$ bar containing 29 nozzles (Type JA2) and a spraying pressure of 5 bars.

\subsection{Sampling and analyses}

A 4.5-cm diameter galvanized-steel auger was used for sampling at depths of $0-0.05,0.05-0.10,0.10-0.20$ and $0.20-$ $0.30 \mathrm{~m} \mathrm{6,12}$ and 18 months after applying lime. For each layer, five
System

Rates

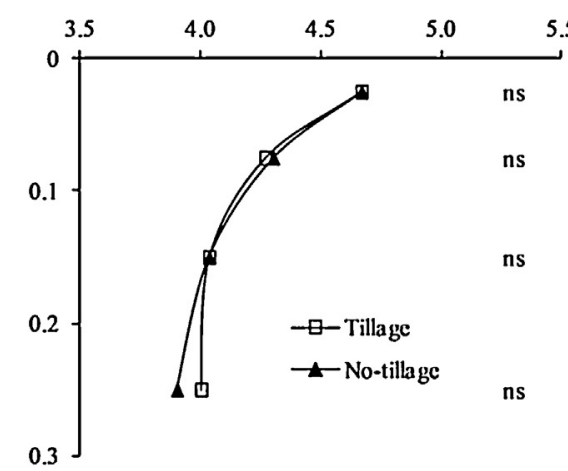

\section{pH (0.01 mol L $\left.{ }^{-1} \mathrm{CaCl}_{2}\right)$}
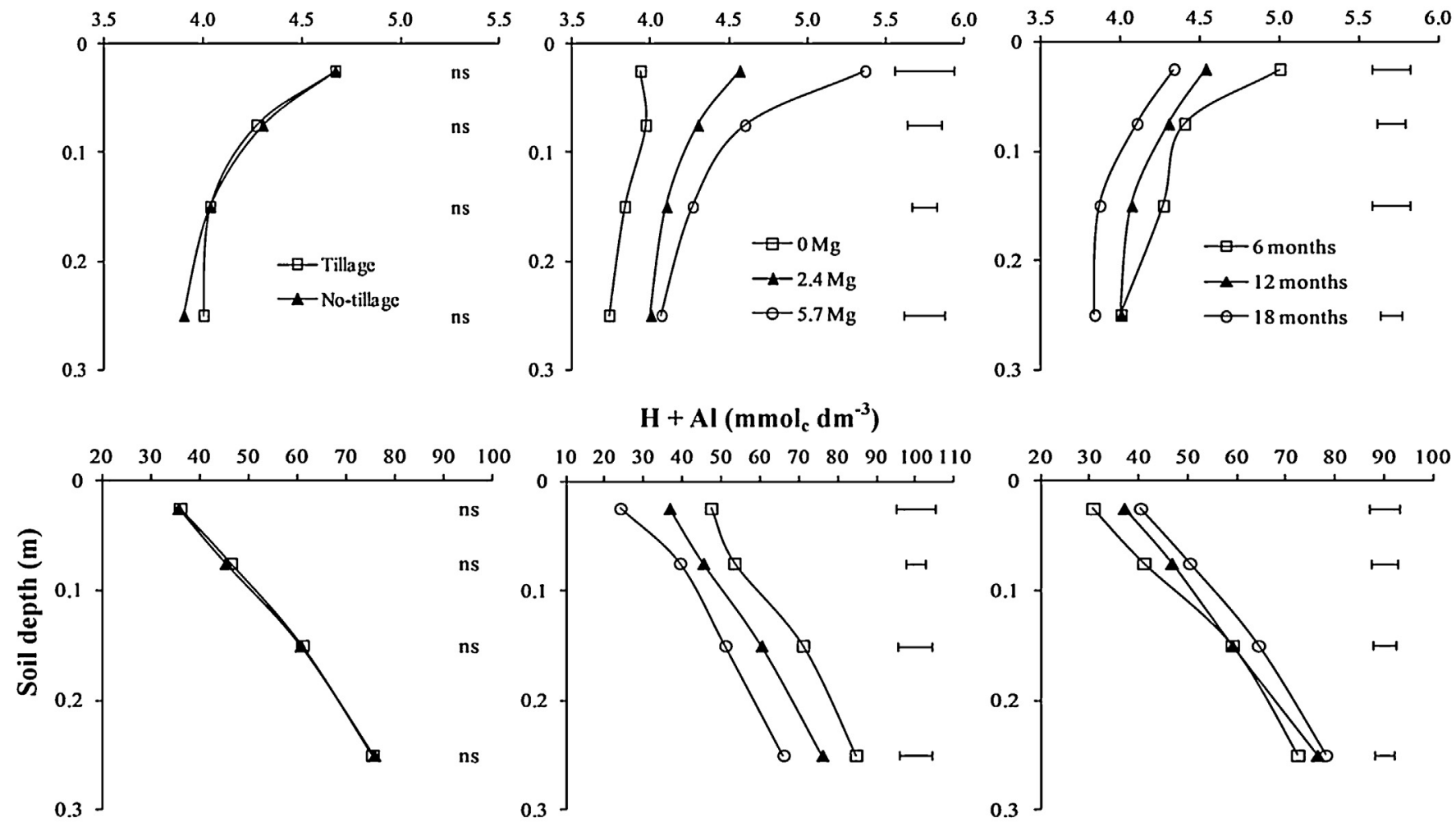

$\mathrm{H}+\mathrm{Al}\left(\mathrm{mmol}_{\mathrm{c}} \mathrm{dm}^{-3}\right)$
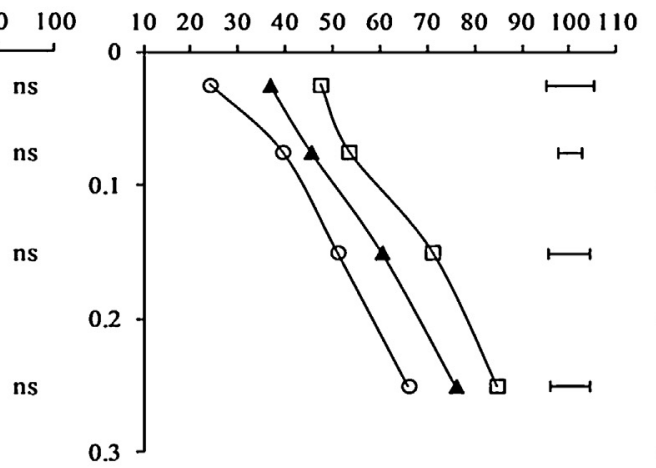

0.3

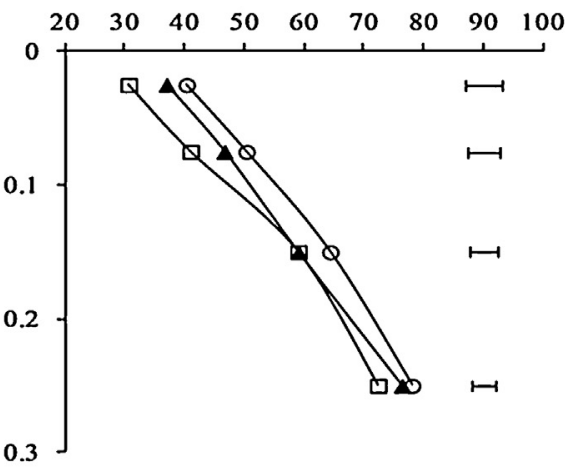

Exchangeable $\mathrm{Al}^{3+}\left(\mathrm{mmol}_{\mathrm{c}} \mathrm{dm}^{-3}\right)$
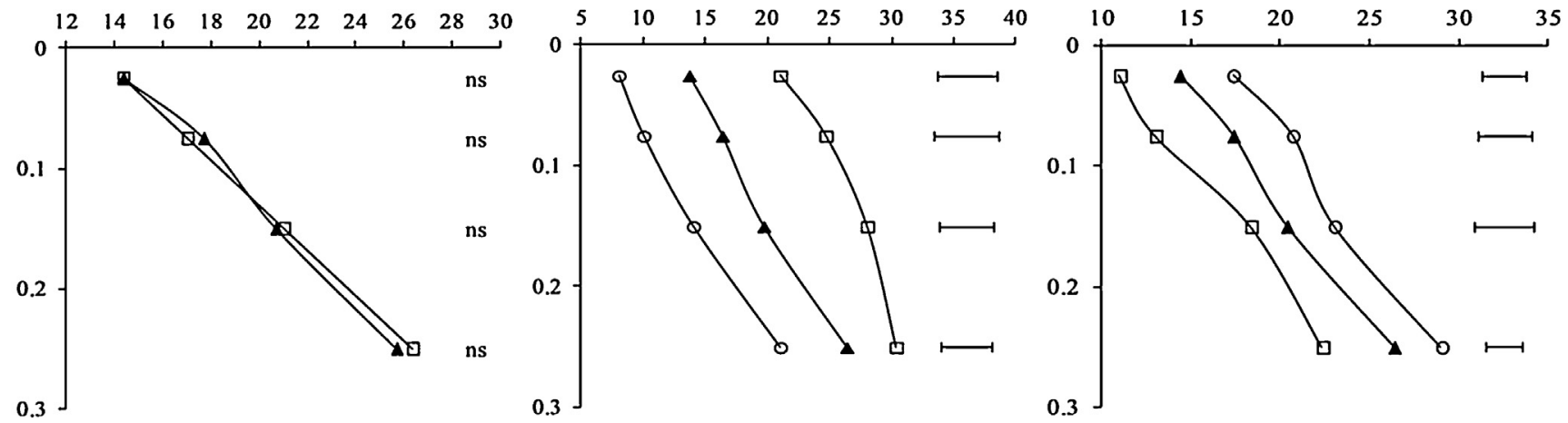

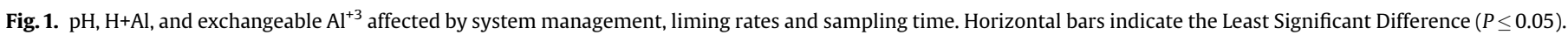
ns, not significant. 
subsamples were collected between the corn inter-rows $(0.45 \mathrm{~m}$ from the plant row) of each subplot. The five subsamples were combined to form one composite sample.

The composite samples were air dried, sieved ( $2 \mathrm{~mm}$ mesh) and stored before analyzing to determine the soil $\mathrm{pH}\left(\mathrm{CaCl}_{2} 0.01 \mathrm{~mol}\right.$ $\mathrm{L}^{-1}$ ) and $\mathrm{P}$, exchangeable $\mathrm{Al}^{+3}, \mathrm{Mg}, \mathrm{Ca}$, and $\mathrm{K}, \mathrm{H}+\mathrm{Al}$ contents. In addition, the base saturation (V\%) was determined according to the methodology proposed by van Raij et al. (2001).

Leaf corn sampling for nutrient concentration analysis was performed when $50 \%$ of the corn plants were in their full flowering stage. Twenty plants per subplot were randomly analyzed, and the leaf opposite the highest ear was sampled as proposed by Cantarella et al. (1997). Next, the leaf samples were washed, dried using forced air circulation at $65^{\circ} \mathrm{C}$ for $72 \mathrm{~h}$ and ground. The N, P, K, $\mathrm{Ca}$, and $\mathrm{Mg}$ concentrations in the leaves were determined according to the methods described by Malavolta et al. (1997). Next, $\mathrm{N}$ was extracted using $\mathrm{H}_{2} \mathrm{SO}_{4}$, and other nutrients were extracted using a nitro-perchloric solution. From the extracted solution, the $\mathrm{N}$ concentration was determined by using the Kjeldahl distiller method, and the $\mathrm{P}, \mathrm{K}, \mathrm{Ca}$, and $\mathrm{Mg}$ concentrations were determined using spectrophotometry.

Grain harvest occurred seven days after the corn reached physiological maturity and was performed using a Nursery Máster Elite Wintersteiger small-plot harvester. The grain yield was measured from the usable area in each subplot. Next, the corn grain weight from the usable area was determined, and the data were transformed to grain yield in $\mathrm{ha}^{-1}\left(130 \mathrm{~g} \mathrm{~kg}^{-1}\right.$ wet basis). Then, the final plant population was determined by counting the number of plants in the three central rows over distances of eight meters in each subplot. When determining the plant population, the plant

\section{System}

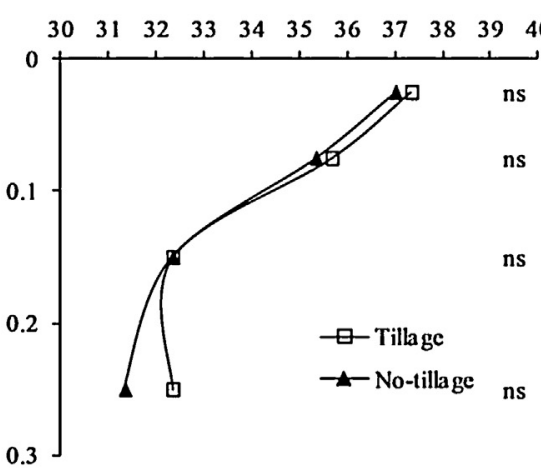

Rates

\section{Soil organic matter $\left(\mathrm{g} \mathrm{dm}^{-3}\right)$}

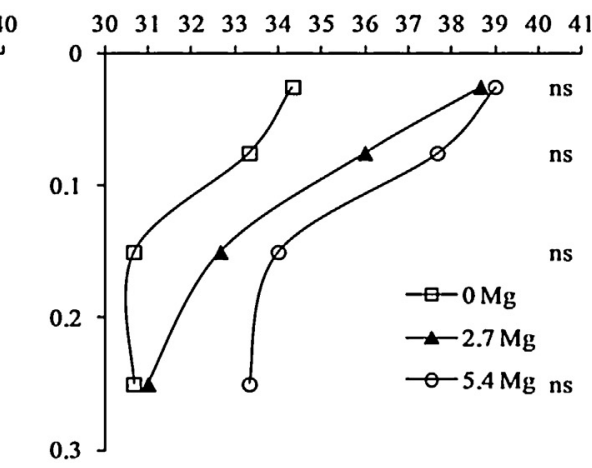

P resin ( $\left.\mathrm{mg} \mathrm{kg}^{-1}\right)$
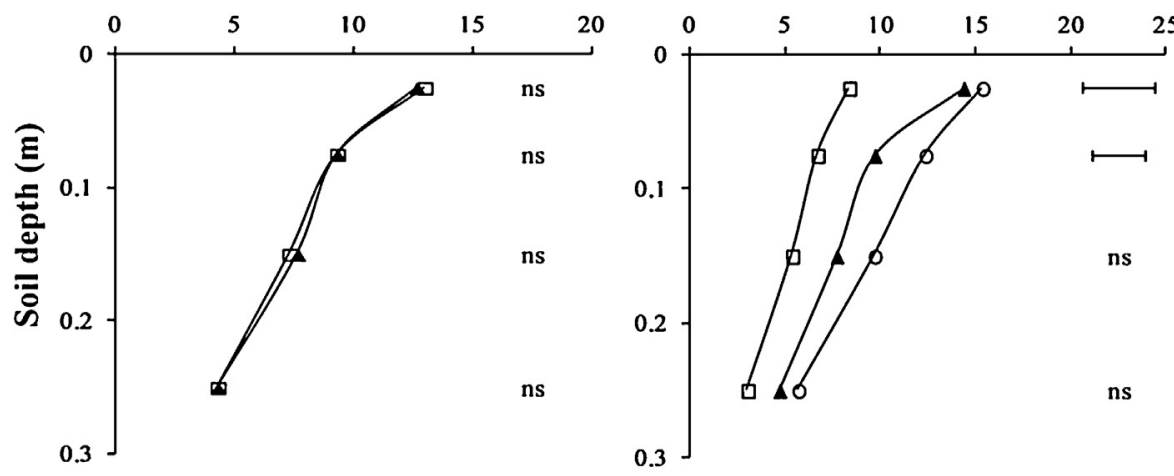

\section{Exchangeable $\mathrm{Ca}^{2+}\left(\mathrm{mmol}_{\mathrm{c}} \mathrm{dm}^{-3}\right)$}
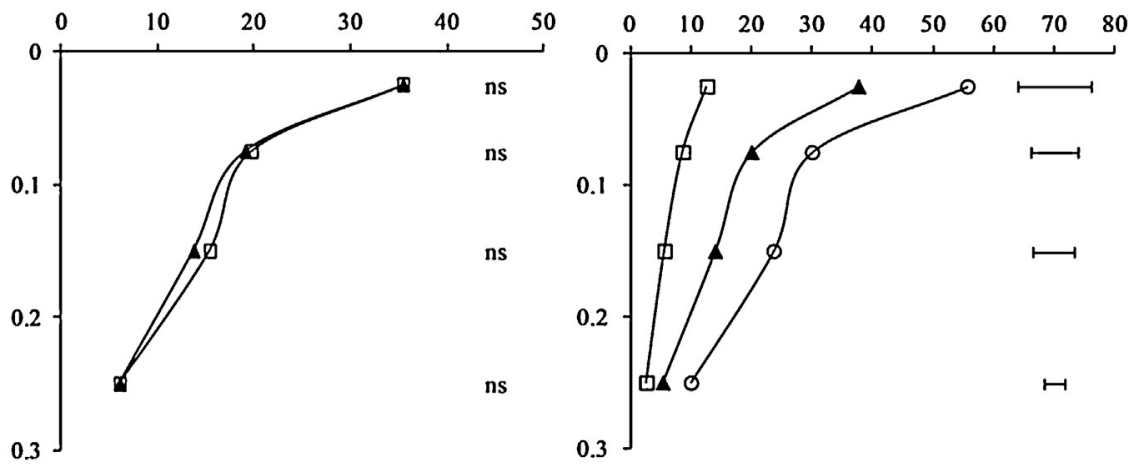
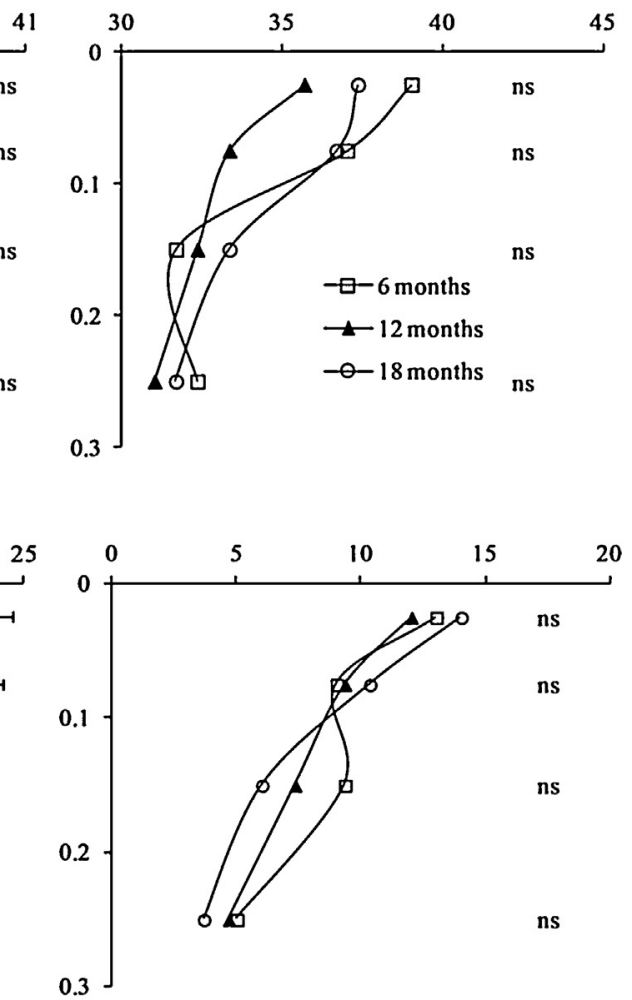

\section{Sampling time}

0.3

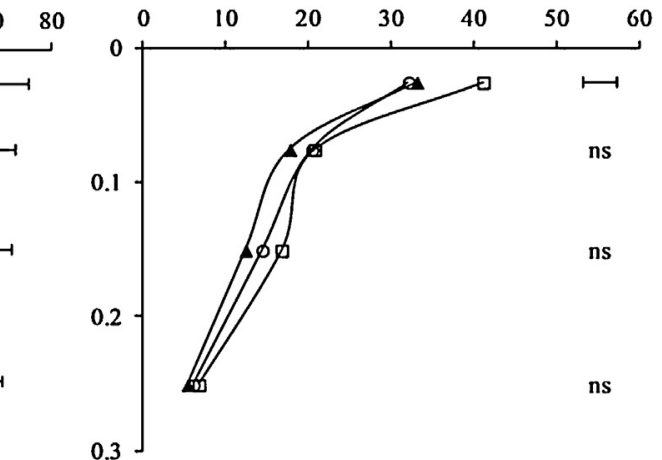

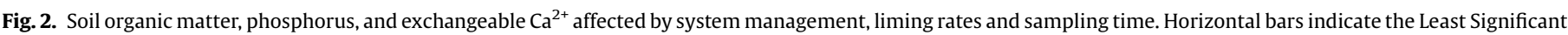
Difference $(P \leq 0.05)$. ns, not significant. 
height, number of ears per plant, number of grains per ear, and weight of 100 grains were evaluated from 10 plants per subplot that were randomly chosen in the usable area.

\subsection{Statistical analyses}

All data were analyzed using the SAS Statistical Software Package. Management system, liming rates, sampling time (only for soil chemical attributes), and growing season (only for plant analysis) were all considered to have fixed effects. Mean separations were conducted using an LSD test. Effects were considered statistically significant at $P \leq 0.05$.

\section{Results}

\subsection{Soil attributes}

With respect to the chemical properties of the soil, no interaction was observed between the management systems, liming rates, and sampling time (Table 3 ). The single effects of these factors will be discussed separately.

Compared with superficial liming, the incorporation of the soil acidity amendment did not result in significant changes in the main soil chemical attributes, including the active acidity $(\mathrm{pH})$, potential acidity $(\mathrm{H}+\mathrm{Al})$, exchangeable acidity $\left(\mathrm{Al}^{3+}\right)$, soil organic matter (SOM), macronutrients levels $\left(\mathrm{P} \mathrm{Ca}^{2+}, \mathrm{Mg}^{2+}\right.$ and $\mathrm{K}^{+}$) and base saturation values (Figs. 1-3).

\section{System}

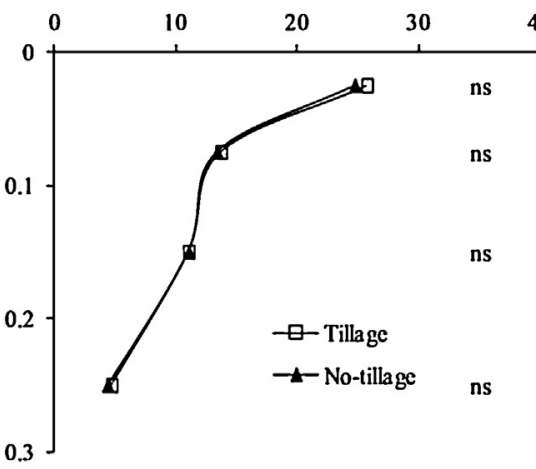

Rates

\section{Exchangeable $\mathrm{Mg}^{2+}\left(\mathrm{mmol}_{\mathrm{c}} \mathrm{dm}^{-3}\right)$}

\section{Sampling time}

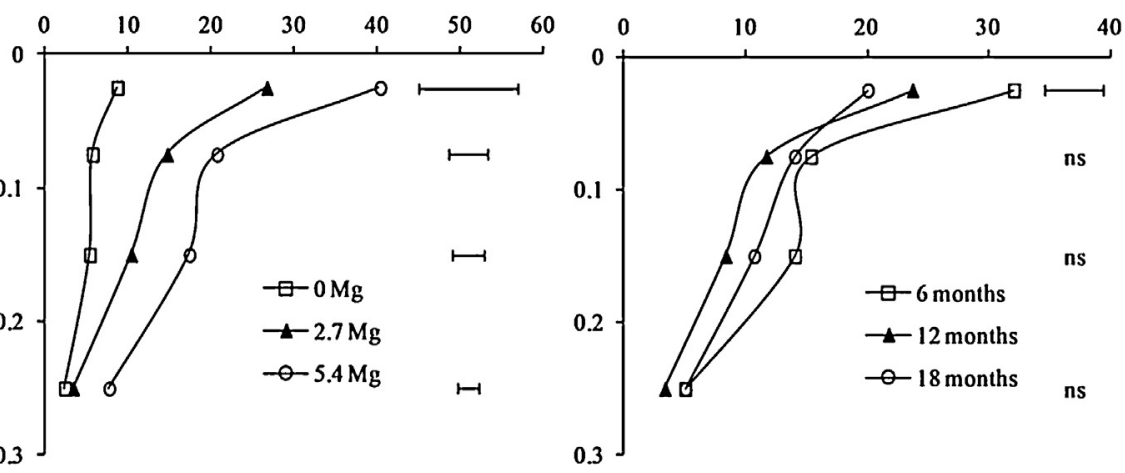

\section{Exchangeable $\mathrm{K}^{+}\left(\mathrm{mmol}_{\mathrm{c}} \mathrm{dm}^{-3}\right)$}
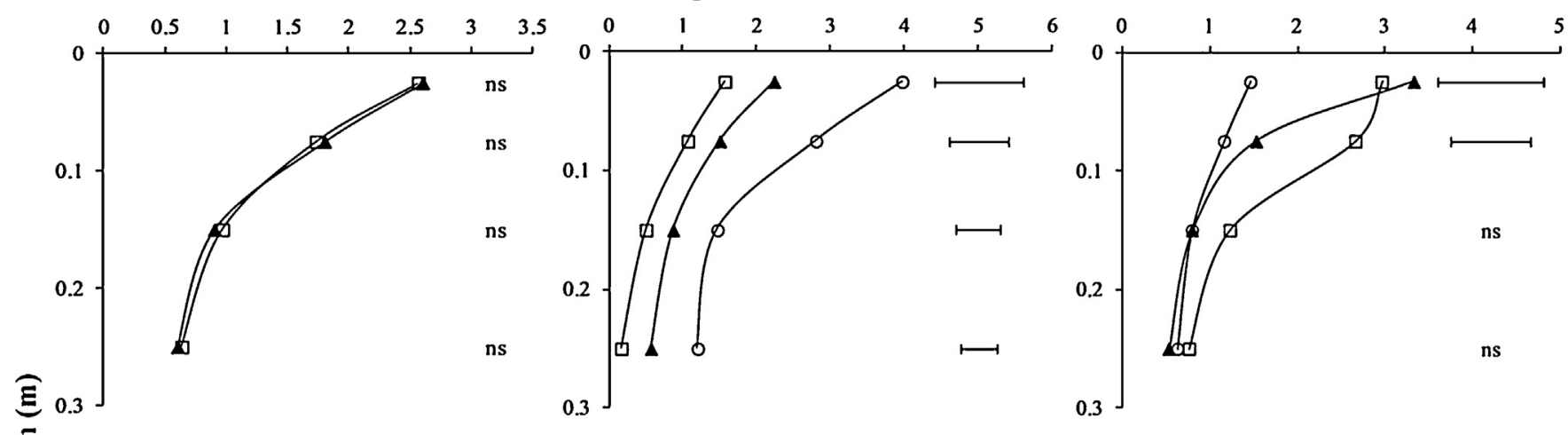

Base saturation (\%)

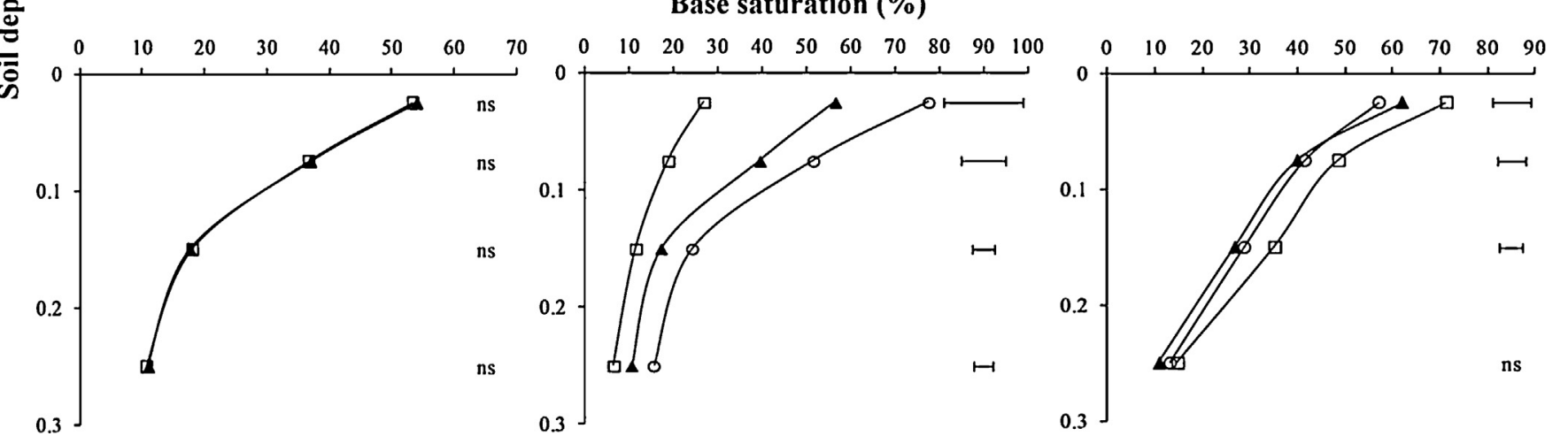

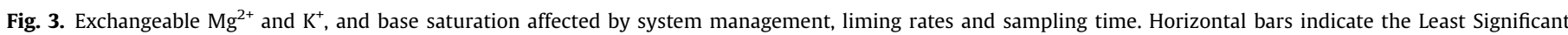
Difference $(P \leq 0.05)$. ns, not significant. 
The application of the recommended rate $\left(5.4 \mathrm{Mg} \mathrm{ha}^{-1}\right)$, regardless of the system management, resulted in significant changes in the $\mathrm{pH}$; exchangeable $\mathrm{Ca}^{2+}, \mathrm{Mg}^{2+}$, and $\mathrm{K}^{+}$levels; and base saturation, and reduced the level of exchangeable $\mathrm{Al}^{3+}$ and $\mathrm{H}$ $+\mathrm{Al}$ in all of the evaluated profiles $(0-0.30 \mathrm{~m}$ ) (Figs. $1-3)$. Despite the less expressive effect, applying half of the rate $\left(2.7 \mathrm{Mg} \mathrm{ha}^{-1}\right)$ was sufficient for reducing acidity and increasing the levels of divalent bases $\left(\mathrm{Ca}^{2+}\right.$ and $\left.\mathrm{Mg}^{2+}\right)$, which resulted in significant increases in the base saturation values. However, the action of the lowest rate of lime was limited to a depth of $0.20 \mathrm{~m}$.

The strongest liming action was verified after six months of treatments establishment (first sampling), which highlighted the rapid responses of the soils to soil amendment practices in all of the evaluated profiles (up to $0.30 \mathrm{~m}$ depth). For $\mathrm{pH}$ values, an increase of this index was observed at the surface layer $(0-0.05 \mathrm{~m})$, with a 1.1 increase in the $\mathrm{pH}$ scale after six months of lime application. The third sampling ( 18 months) showed the acidifying effects of soil during the trial period, and a decrease in this index was observed over time in all of the evaluated layers.

Regarding the levels of SOM and P, no differences were observed between the sampling time (Fig. 2). In addition, increases in basic cation levels $\left(\mathrm{Ca}^{2+}, \mathrm{Mg}^{2+}\right.$ and $\mathrm{K}^{+}$) increased up to a depth of approximately $0.30 \mathrm{~m}$ relative to the original soil cation levels (before treatments establishment). Beginning from the first sampling, a decrease in exchangeable $\mathrm{Ca}^{2+}, \mathrm{Mg}^{2+}$ and $\mathrm{K}^{+}$levels was observed in the $0-0.05$ and $0.05-0.10 \mathrm{~m}$ layers. In addition, a decrease in the $0.10-0.20 \mathrm{~m}$ layers for $\mathrm{K}^{+}$was also detected.

Regarding base saturation, an index of $70 \%$ was only observed in the surface layer $(0-0.05 \mathrm{~m})$ six months after limestone application, regardless of the amount used (Fig. 3). After 12 months, the base saturation values decreased up to a depth of $0.20 \mathrm{~m}$. However, this downward trend was not observed 18 months after applying the acidity amendment because this index remained unchanged relative to the values obtained during the second sampling.

\subsection{Nutrient concentrations in corn leaves}

The macronutrient concentrations were not changed by the soil tillage practices (Table 4 ). Regarding the effects of liming, the only

\section{Table 4}

Nitrogen, phosphorus, potassium, calcium, and magnesium concentrations in the leaves of corn as affected by two management system and lime rates in two growing season. Botucatu, State of São Paulo, Brazil.

\begin{tabular}{llllll}
\hline Treatments & $\mathrm{N}$ & $\mathrm{P}$ & $\mathrm{K}$ & $\mathrm{Ca}$ & $\mathrm{Mg}$ \\
\hline Management system & & & $\mathrm{g} \mathrm{kg}^{-1}$ & & \\
No-tillage & $23 \mathrm{a}$ & $2.1 \mathrm{a}$ & $17.8 \mathrm{a}$ & $5.0 \mathrm{a}$ & $2.5 \mathrm{a}$ \\
Tillage & $24 \mathrm{a}$ & $2.2 \mathrm{a}$ & $16.7 \mathrm{a}$ & $5.0 \mathrm{a}$ & $2.5 \mathrm{a}$ \\
& & & & & \\
Limestone rates & & & & & \\
0 & $21 \mathrm{~b}$ & $2.2 \mathrm{a}$ & $17.4 \mathrm{a}$ & $4.9 \mathrm{a}$ & $2.5 \mathrm{a}$ \\
2.7 & $24 \mathrm{a}$ & $2.3 \mathrm{a}$ & $17.3 \mathrm{a}$ & $5.0 \mathrm{a}$ & $2.3 \mathrm{a}$ \\
5.4 & $25 \mathrm{a}$ & $2.1 \mathrm{a}$ & $17.1 \mathrm{a}$ & $5.0 \mathrm{a}$ & $2.5 \mathrm{a}$ \\
& & & & & \\
Growing season & & & & & \\
First & $22 \mathrm{~b}$ & $2.1 \mathrm{a}$ & $14.9 \mathrm{~b}$ & $3.0 \mathrm{~b}$ & $2.1 \mathrm{~b}$ \\
Second & $24 \mathrm{a}$ & $2.2 \mathrm{a}$ & $19.6 \mathrm{a}$ & $6.9 \mathrm{a}$ & $2.9 \mathrm{a}$ \\
& & & & & \\
F probality & & & & & \\
Blocks & 0.3456 & 0.2358 & 0.2277 & 0.5685 & 0.1728 \\
Management system (S) & 0.3376 & 0.4645 & 0.3421 & 0.1127 & 0.1258 \\
Limestone rates (R) & 0.2063 & 0.0922 & 0.5747 & 0.5876 & 0.3302 \\
Growing season (GS) & $<0.0001$ & 0.2653 & $<0.0001$ & $<0.0001$ & 0.0012 \\
S $\times$ R & 0.3275 & 0.4861 & 0.7456 & 0.5562 & 0.4962 \\
S $\times$ GS & 0.6425 & 0.2953 & 0.5927 & 0.7419 & 0.3119 \\
R $\times$ GS & 0.3852 & 0.4731 & 0.4284 & 0.2048 & 0.7924 \\
S $\times$ R $\times$ GS & 0.7312 & 0.8762 & 0.2772 & 0.3741 & 0.5577 \\
\hline
\end{tabular}

Means followed by different letters in the column differ statistically by the LSD test $(p \leq 0.05)$. significant effect observed was for $\mathrm{N}$ assimilation. No differences were observed between the quantities of lime applied ( 2.7 or $5.4 \mathrm{Mgha}^{-1}$ ). The analysis of variance results for the nutrient concentration in the leaves did not show interactions between the management systems, liming rates, and growing season. In addition, the leaf $\mathrm{N}, \mathrm{K}, \mathrm{Ca}$, and $\mathrm{Mg}$ contents were greater during the second year.

\subsection{Plant height, yield components, and corn grain yield}

The manner of lime application did not affect any of the corn yield components (Table 5). Except for the plant population and number of ears per plant, the yield components and plant height benefitted from lime application. The surface application of the soil acidity amendment resulted in higher values regarding vegetative and reproductive development, regardless of the amount of lime applied. The plant height, yield components, and grain yield had values that were greater than those in the control $\left(0 \mathrm{Mg} \mathrm{ha}^{-1}\right)$. In addition, no interactions occurred between the factors, and the growing season had an isolated affect on the 100 grain-weight, with higher values during the first year.

\section{Discussion}

\subsection{Soil attributes}

Regardless of the method used for lime application into the soil, the addition of the acidity amendment improved the main soil chemical properties, with evident benefits up to a depth of $0.30 \mathrm{~m}$ (Figs. 1-3). Although Ca and Mg carbonates have low solubility and mobility in soil, the results showed a rapid reaction to surface liming over a relative short period. Thus, soils cultivated with perennial forage species generally produce a stable structure and good porosity (Cavalieri et al., 2009; Cavallini et al., 2010), which allows carbonate percolation through the soil profile, without the need for mechanical incorporation. In addition to the factors that determine the physical quality of soil, water availability and lime rates are important for the viability of this practice (Rheinheimer et al., 2000; Soratto and Crusciol, 2008). According to Miyazawa et al. (2002) and Calegari et al. (2013), the pluvial regime strongly interferes on reaction speed of carbonate in the sub-surface layers because water is an important vehicle for displacing limestone particles. According to Salton et al. (2008), the inclusion of perennial forage in agricultural systems is critical for increasing the soil porosity. The roots of these species formed porous channels due to the aggregation of solid particles, which likely improved the percolation of water containing suspended limestone fragments.

When comparing the effects of surface liming (no-tillage) and the incorporation of lime by plowing and disking (conventional), Rheinheimer et al. (2000) found that surface liming had limited effect on the profile of a Argisol distrophic medium-textured. By contrast, Oliveira and Pavan (1996) studied a clayey Latosol and showed that the variables related to acidity ( $\mathrm{pH}$ and exchangeable $\mathrm{Al}^{3+}$ ) were affected at depths of up to $0.4 \mathrm{~m}$. The benefits observed in the shallow soil layers regarding the soil chemical attributes were also highlighted by Soratto and Crusciol (2008). These authors emphasize that maintaining soil structure was critical for the reaction speed of the limestone in the subsurface. Although surface liming had a limited affect on the soil profile over a short period (Pöttker and Ben, 1998; Caires et al., 2006; Caires et al., 2008), the authors noted that restrictive action can vary depending on the mobility of $\mathrm{OH}^{-}$and $\mathrm{HCO}_{3}{ }^{-}$ions in the soil. Researchers have emphasized that certain organic and inorganic compounds can increase the affects of surface liming in shallow soils by increasing the mobility of basic cations, which can reduce the negative effect of free $\mathrm{Al}^{3+}$, an important component of acidity 
Table 5

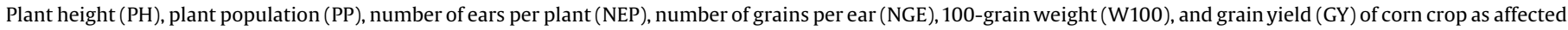
by two management system and lime rates application in two growing season. Botucatu, State of São Paulo, Brazil.

\begin{tabular}{|c|c|c|c|c|c|c|}
\hline Treatments & $\mathrm{PH}$ & $\mathrm{PP}$ & NEP & NGE & W100 & GY \\
\hline Management system & $\mathrm{m}$ & $\mathrm{n}^{\circ}$ & $\mathrm{n}^{\circ}$ & $\mathrm{n}^{\circ}$ & $\mathrm{g}$ & $\mathrm{kg} \mathrm{ha}^{-1}$ \\
\hline No-tillage & $1.72 \mathrm{a}$ & 53145 a & $1.05 \mathrm{a}$ & $501 \mathrm{a}$ & $29.3 \mathrm{a}$ & 8045 a \\
\hline Tillage & $1.72 \mathrm{a}$ & 53354 a & $1.06 \mathrm{a}$ & 519 a & $29.2 \mathrm{a}$ & 8141 a \\
\hline \multicolumn{7}{|l|}{ Limestone rates } \\
\hline 0 & $1.62 \mathrm{~b}$ & $52514 \mathrm{a}$ & $1.04 \mathrm{a}$ & $473 \mathrm{~b}$ & $28.4 \mathrm{~b}$ & $6983 \mathrm{~b}$ \\
\hline 2.7 & $1.76 \mathrm{a}$ & 53499 a & $1.07 \mathrm{a}$ & $521 \mathrm{a}$ & $30.0 \mathrm{a}$ & 8427 a \\
\hline 5.4 & $1.75 \mathrm{a}$ & 53739 a & $1.07 \mathrm{a}$ & 537 a & 29.6 a & 8869 a \\
\hline \multicolumn{7}{|l|}{ Growing season } \\
\hline First & $1.70 \mathrm{a}$ & 53333 a & $1.05 \mathrm{a}$ & $497 \mathrm{a}$ & $30.2 \mathrm{a}$ & 8042 a \\
\hline Second & $1.74 \mathrm{a}$ & 53167 a & $1.06 \mathrm{a}$ & $523 \mathrm{a}$ & $28.4 \mathrm{~b}$ & 8144 a \\
\hline \multicolumn{7}{|l|}{ F probality } \\
\hline Blocks & 0.8323 & 0.5729 & 0.3556 & 0.6839 & 0.4739 & 0.2959 \\
\hline Management system (S) & 0.0965 & 0.1148 & 0.4629 & 0.1622 & 0.3824 & $<0.0001$ \\
\hline Limestone rates $(\mathrm{R})$ & $<0.0001$ & 0.0931 & 0.2275 & $<0.0001$ & $<0.0001$ & $<0.0001$ \\
\hline Growing season (GS) & 0.3171 & 0.2277 & 0.6784 & 0.0981 & $<0.0001$ & 0.2873 \\
\hline $\mathrm{S} \times \mathrm{R}$ & 0.2483 & 0.5394 & 0.7239 & 0.4785 & 0.4376 & 0.5521 \\
\hline $\mathrm{S} \times \mathrm{GS}$ & 0.4629 & 0.2841 & 0.5625 & 0.3367 & 0.6294 & 0.4674 \\
\hline $\mathrm{R} \times \mathrm{GS}$ & 0.3529 & 0.2749 & 0.3739 & 0.3472 & 0.3698 & 0.2341 \\
\hline $\mathrm{S} \times \mathrm{R} \times \mathrm{GS}$ & 0.3121 & 0.2342 & 0.1627 & 0.2849 & 0.3421 & 0.3929 \\
\hline
\end{tabular}

Means followed by different letters in the column differ statistically by the LSD test $(p \leq 0.05)$.

(Franchini et al., 2003; Castro et al., 2012). According to Caires et al. (2000), superficial liming is a viable technique because it can promote improvements in soil chemical attributes below to a depth of $0.30 \mathrm{~m}$, depending on the characteristics of the soil and the environmental conditions. The changes observed in $\mathrm{pH}$, potential acidity $(\mathrm{H}+\mathrm{Al})$, exchangeable $\mathrm{Al}^{3+}, \mathrm{Ca}^{2+}, \mathrm{Mg}^{2+}$ and $\mathrm{K}^{+}$ levels and the soil base saturation resulting from different limestone rates indicated that lime was effective for improving soil chemical attributes up to a depth of $0.30 \mathrm{~m}$. The effect of liming to a depth of $0.30 \mathrm{~m}$ was observed in a no-tillage system in Kentucky (U.S.A.). However, the rate required to affect chemical properties of the soil at a depth of $0.3 \mathrm{~m}$ was three times higher than the calculated rate (Blevins et al., 1978).

Apart from the applied rate, a reduction in the various components of acidity occurred. However, the largest benefits were observed with the application of the recommended rate (Fig. 1). According to Joris et al. (2013), the effects of liming on the availability of the exchangeable $\mathrm{Al}^{3+}$ can vary depending on the amount of carbonate and the depth that must be achieved. At all rates of surface limestone tested, the authors observed that the $\mathrm{Al}^{3+}$ levels were reduced to very low levels $\left(\leq 2 \mathrm{mmol}_{\mathrm{C}} \mathrm{L}^{-1}\right)$ in the upper soil layers $(0-0.05$ and $0.05-0.10 \mathrm{~m})$. However, only the highest application rate $\left(12 \mathrm{Mg} \mathrm{ha}^{-1}\right)$ reduced the exchangeable $\mathrm{Al}^{3+}$ level in the $0.10-0.20 \mathrm{~m}$ layer. These authors confirmed the relationship between the soil $\mathrm{pH}$ and exchangeable $\mathrm{Al}^{3+}$ that were observed by Limousin and Tessier (2007). In addition, an increase in $\mathrm{pH}$ encourages soluble $\mathrm{Al}^{3+}$ alteration to forms that are non-toxic to plants. This effect reduced the exchangeable $\mathrm{Al}^{3+}$ levels in the soil, which probably can explain the decreasing trend on the potential acidity $(\mathrm{H}+\mathrm{Al})$. Although, in the $0.20-0.30 \mathrm{~m}$ soil layer only the recommended rate resulted in a significant reduction in exchangeable $\mathrm{Al}^{3+}$. This difference is probably related to minor variations in soil pH, as already indicated by Kaminski et al. (2002). In addition to the effects of the setting, it is important to note that the morphological characteristics of the root system and the kinetics of nutrient absorption by perennial forage species can also reduce the toxicity of exchangeable $\mathrm{Al}^{3+}$ (Wenzl et al., 2001). This effect could result from changes in the dynamics of $\mathrm{H}^{+}$efflux and influx, which would promote significant changes in $\mathrm{pH}$, and the precipitation of toxic elements in rhizospheric soil, as noted by Nye (1981).

The greater availability of $\mathrm{Ca}^{2+}, \mathrm{Mg}^{2+}$ and $\mathrm{K}^{+}$in all soil layers was only verified by implementing the recommended rate $(5.4 \mathrm{Mg}$ $\mathrm{ha}^{-1}$ ). However, the highest exchangeable bases levels were observed in the 0-0.05 m layer, as noted by Conyers et al. (2003) and Soratto and Crusciol (2008). According to Mello et al. (2003), the high levels of basic cations in the surface layer resulted in $\mathrm{pH}$ increases at the soil surface, which increased the rate of movement of carbonate ions (accompanied with $\mathrm{Ca}$ and $\mathrm{Mg}$ ) into deeper soil layers to neutralize or reduce the acidity of the sub-surface layers. The highest $\mathrm{pH}$ value in the surface soil probably influenced the downward movement of $\mathrm{HCO}_{3}{ }^{-}$ion, which was accompanied by $\mathrm{Ca}$ and $\mathrm{Mg}$, moved to the adjacent lower layers and reacted with the acidity. According to Rheinheimer et al. (2000), when acidic cations are present, the acidity neutralization reaction will be limited to the top layer, which delays the appearance of effects in the subsurface. According to the authors, one of the main factors that contributes to the reactivity of the limestone in the subsurface is the preservation of the physical soil properties.

In addition to the physical factors, the mobility of basic cations $\left(\mathrm{Ca}^{2+}, \mathrm{Mg}^{2+}\right.$ and $\left.\mathrm{K}^{+}\right)$in the soil profile may be enhanced by the formation of water-soluble organic complexes. Changing the loading of these cations by reaction with organic compounds can facilitate the mobility of both ions through the soil. In the subsurface layer, the presence of acidic ions $\left(\mathrm{H}^{+}\right.$or $\left.\mathrm{Al}^{3+}\right)$ can stimulate the release of $\mathrm{Ca}, \mathrm{Mg}$ and $\mathrm{K}$ complexes (Miyazawa et al., 2002; Franchini et al., 2003). This reaction increases levels of basic cations which are necessary to raise root growth in acidic soils.

Unlike the soil basic cations, the soil P levels only changed in the superficial layers (0-0.05 and 0.05-0.10 m) (Figs. 1-3). The effects of liming on the availability of $P$ are likely related to the increased action of carbonate in the surface layers, since increments of 0.7 and $1.5 \mathrm{pH}$ units were observed in the $0-0.05$ soil layer and increments of 0.3 and 0.6 were observed in the $0.05-0.10$ soil layer with the application of 2.7 and $5.4 \mathrm{Mg} \mathrm{ha}^{-1}$, respectively. In highly weathered soils, which are rich in $\mathrm{Fe}$ and $\mathrm{Al}$ oxides, the variations in $\mathrm{pH}$ determine the electrical charges on the interfaces of the organo-mineral particles. Increases in the $\mathrm{pH}$ index favor the 
development of negative charges, which increase phosphate mobility and decrease $\mathrm{P}$ adsorption due to ligand exchange (Parfitt, 1978; Barrow, 1985). According to Alleoni et al. (2003), this problem can also be attributed to the increased release of watersoluble organic acids in the soil. The chemical structures of these acids govern their adsorption because some molecules have preferential exchange sites and compete with phosphate, which reduces the reactions that cause $P$ precipitation (Andrade et al., 2003). Among the main factors that influence the competition of these compounds with the colloidal complex sites, the soil $\mathrm{pH}$ is notable (Pavinato and Rosolem, 2008). As in the lower layers, variations in the soil pH were minor, no changes in the availability of $\mathrm{P}$ occurred below a depth of $0.10 \mathrm{~m}$.

Despite encouraging the input of organic matter into soil (Castro et al., 2015), it is assumed that the absence of an effect is related to the time of sampling, which is probably insufficient for promoting significant changes in this attribute. The effects of the absence of tillage on the SOM were potentially related to the low level of this fraction in tropical soils (Zech et al., 1997). Moreover, the $\mathrm{pH}$ modification did not allow for high proliferation of mineralization organisms, which have a higher activity at neutral $\mathrm{pH}$ or under alkaline conditions (Rousk et al., 2009).

Independent of the management system and the amount of lime applied, greater soil chemical effects were observed for the acidity amendment practices during the first sampling (six months) (i.e., most of the limestone reacted during the first few months). These results were probably related to the high ECCE (82\%) (Aguilar et al., 2009). According to Gonçalves et al. (2011), the reaction speed of the limestone and its residual effect are inverse. Consequently, greater limestone reactivity indicates that the product can be kept for a shorter period.

The changes in the various components of acidity $(\mathrm{pH}$, exchangeable $\mathrm{Al}^{3+}$ and $\mathrm{H}+\mathrm{Al}$ ) observed over time were mainly associated with the action of acid reaction fertilizers, such as ammonium (Conyers et al., 1995; Crusciol et al., 2011). Although the nitrification process can be consider an important acidifying agent, greater anion $\mathrm{NO}_{3}{ }^{-}$levels in the soil solution may contribute to the migration of basic cations through the soil profile. According to Caires et al. (2015), the application of nitrogen fertilizer in soil can intensify $\mathrm{Ca}^{2+}$ and $\mathrm{Mg}^{2+}$ percolation through the soil profile. The authors observed increments of these cations at depths below $0.30 \mathrm{~m}$. Although the mobility of these cations may be influenced by the formation of a complex cation-ligand, the reduction in the saturation value over the experimental period probably is related to associated to the amount of these nutrients removed by harvesting (Oliveira and Pavan, 1996).

\subsection{Nutrient concentration in corn leaves}

The effects of liming on the $\mathrm{N}$ concentration are potentially related to the availability of nitrate in the soil. According to Silva and Vale (2000), soil acidity is one of the main factors that limit the activity of nitrification organisms. Overall, the authors observed that the mean synthesis of nitrate by microorganisms was $11.6 \mathrm{mg} \mathrm{kg}^{-1}$ in acid soils, without the addition of lime; however, in amended soils, up to $62.7 \mathrm{mg} \mathrm{kg}^{-1}$ of nitrate were produced. In addition to the benefits of application on biological soil properties, liming results in better conditions for the development of root systems, even when only applied on the soil surface. These improved conditions result in greater areas of useable soil and favor increases in the uptake of nutrients, such as $\mathrm{N}$ (Caires et al., 2002). In addition to the factors that are favorable for increasing $\mathrm{N}$ availability, it is important to understand that the $\mathrm{N}$ leaf concentration for the corn crops are below the minimum levels that are adequate for crop growth, even in the treatments that received lime (Cantarella et al., 1997).
The absence of any treatment effect on the P, K, Ca, and Mg concentrations in corn leaves may be related to a sufficient supply of these elements through mineral fertilization and the nutrient cycling, process governed by microbiological activity. Regardless of the treatment, the concentrations of these nutrients were within the ranges considered adequate for corn crop (Cantarella et al., 1997). In soybean crops, Moreira et al. (2001) observed that the leaf $\mathrm{P}$ and $\mathrm{K}$ concentrations did not change following the immediate application of soil acidity amendments, and Caires et al. (1998) observed that surface liming does not affect the $\mathrm{N}, \mathrm{K}$, and $\mathrm{Ca}$ concentrations in soybean leaves.

Regarding the growing season, the leaf concentration of $\mathrm{N}$ was greater in the second year. This result is potentially related to the climatic conditions that occurred during each growing season, which potentially affected the $\mathrm{N}$ dynamics in the soil (Weber and Mielniczuk, 2009).

The $\mathrm{K}$ concentration during the first growing season was lower than the adequate range for the crop. However, during the second year, a generalized increase in the $\mathrm{K}$ concentration in the leaves occurred, which was above the minimum level considered sufficient for corn crops (Cantarella et al., 1997). The application of lime over time resulted in greater cation exchange capacities (CEC), which favored the occupation of $\mathrm{K}^{+}$at these bonding sites and increased the exchangeable $\mathrm{K}$ level in the soil surface layer (Caires et al., 1998), where the greatest corn root biomass is found (Costa et al., 2009).

Regarding the $\mathrm{K}$ concentration in the leaves, a difference in the $\mathrm{Ca}$ and $\mathrm{Mg}$ concentrations occurred between the growing seasons. During the first year, the leaf Ca concentration was $2.9 \mathrm{~g} \mathrm{~kg}^{-1}$, and during the second year, was $6.7 \mathrm{~g} \mathrm{~kg}^{-1}$. The benefits observed through the reaction time of the product may also be observed in the $\mathrm{Mg}$ concentration in the leaves, which were $2.2 \mathrm{~g} \mathrm{~kg}^{-1}$ and $3.2 \mathrm{~g} \mathrm{~kg}^{-1}$ in the first and second growing season, respectively. In addition to the indirect effects of $\mathrm{pH}$ on the availability of $\mathrm{Ca}$ and $\mathrm{Mg}$, the dolomite is considered an important source of these cations (Amaral and Anghinoni, 2001; Moreira et al., 2001). When evaluating the effects of surface liming on soil chemical properties, Caires et al. (1999) observed greater availability of exchangeable Ca and $\mathrm{Mg}$ in soil 18 months after application, which was reflected by an increase in the $\mathrm{Ca}$ and $\mathrm{Mg}$ concentrations in soybean and wheat plant leaves. Although the growing seasons affected the $\mathrm{Ca}$ and $\mathrm{Mg}$ concentrations in the leaves, during both years, the values were within the range considered adequate for the crop (Cantarella et al., 1997).

\subsection{Plant height, yield components and corn grain yield}

Regarding of the soil management system, the favorable edaphic and climatic conditions occurred during the field experiment period, the soil type, and the use of high quantities of chemical fertilizers likely overshadowed any affects of the method of soil amendment application on corn grain yield. This finding emphasizes the importance of performing these studies over long periods and highlights the relationships of these management systems with liming.

Corn has a high demand for nutrient, as consequence, only the application of intermediate rate $\left(2.7 \mathrm{Mgha}^{-1}\right)$ provided better conditions to corn growth. The soil acidity amelioration and the higher levels of exchangeable $\mathrm{Ca}^{2+}$ and $\mathrm{M}^{2+}$ in the soil contributed to the vegetative and reproductive development of the plants. Furthermore, these results were similar to those related by Pöttker \& Ben (1998) and Caires et al. (2000), who affirmed that lime requirement in NTS is probably lower than that in conventional systems. The effects of improving soil chemical properties on crop development in this study were similar to those observed by Andreotti et al. (2001). 
The benefits of liming on corn yield components were reflected positively in the grain yield, and the highest values were observed with lime use, regardless of the application rate. According to Ferreira et al. (2001), this result is explained by the presence of correlations between nutritional parameters and grain yield, indicating the importance of nutritional diagnosis as a tool for detecting deficiencies and predicting grain yield results. Thus, the benefits of liming on grain yield, regardless of the application rate, are likely related to improvements in the soil chemical conditions, which probably reflected in root system development and, consequently, plant nutrition. According to Caires et al. (2002), the acidity condition in subsoil layers hinders the use of soil by root systems because it confines the roots to the surface layer and, consequently, limits water and nutrient uptake by corn.

The greater grain weight observed in the second growing season could be attributed to environmental conditions. Magalhães and Jones (1990) reported that grain weight is mainly affected by genotype characteristics, which express endosperm cavity. Nevertheless, the number and capacity of endosperm cells may be strongly affected by the edaphic and climatic conditions that occurred during the growing season.

\section{Conclusion}

Our results demonstrate the effectiveness of surface liming on improving the main chemical attributes of tropical soils. After six months of amendment practices, which included applying limestone on soils surface with perennial forage residues (Brachiaria decumbens Stapf. pasture), similar results were observed between the surface and incorporation treatments, with soil mobilization up to a depth of $0.30 \mathrm{~m}$. This depth is beneficial for forage roots and soil aggregation and stability. Liming increased $\mathrm{N}$ concentration in corn leaves, the number of grains per ear, the 100grain weight which resulted in higher hybrid corn grain yield, regardless of application method. The surface application of lime rates showed viability to increase corn grain production in soil with limited forage productivity and low soil chemical fertility.

\section{Acknowledgements}

We acknowledge the National Council for Scientific and Technological Development (CNPq) for financial support (Support Program for Centers of Excellence - PRONEX) and for an award for excellence in research to second, third, and fifth authors.

\section{References}

Alleoni, L.R.F., Zambrosi, F.C.B., Moreira, S.G., Prochnow, L.I., Pauletti, V., 2003. Liming and electrochemical attributes of an oxisol under no tillage. Sci. Agric. 60, 119-123 (In Portuguese, with English abstract).

Amaral, A.S., Anghinoni, I., 2001. Changes in chemical characteristics of the soil profile by surface lime application in no-tillage system. Pesq. Agropec. Bras. 36, 695-702 (In Portuguese, with English abstract).

Andrade, F.V., Mendonça, E.S., Alvarez, V., Novais, R.F., 2003. Addition of organic and humic acids to Latosols and phosphate adsorption effects. R. Bras. Ci. Solo 27, 1003-1011 (In Portuguese, with English abstract).

Andreotti, M., Souza, E.C.A., Crusciol, C.A.C., 2001. Morphologycal components and dry matter accumulation in corn as a function of liming and zinc fertilization. Sci. Agric. 58, 321-327 (In Portuguese, with English abstract).

Barrow, N.J., 1985. Reaction of anions and cations with variable-charge soils. Adv. Agron. 38, 183-230.

Blevins, R.L., Murdock, L.W., Thomas, G.W., 1978. Effect of lime application on notillage and conventionally tilled corn. Agron. J. 70, 322-326.

Borghi, E., Crusciol, C.A.C., Nascente, A.S., Sousa, V.V., Martins, P.O., Mateus, G.P., Costa, C., 2013. Sorghum grain yield, forage biomass production and revenue as affected by intercropping time. Eur. J. Agron. 51, 130-139.

Borlaug, N.E., Dowswell, C.R., 1998. Fertilizer: to nourish infertile soil that feeds a fertile population that crowds a fragile world. Keynote address at the 61 st Annual Conference, International Fertilizer industry Association (IFA), May 2427. 1993, New Orleans, Louisiana, USA 18p.
Briedis, C., Sá, J.C.M., Caires, E.F., Navarro, J.F., Inagaki, T.M., Ferreira, A.O., 2012. Soil carbon and fertility attributes in response to surface liming under no-tillage. Pesq. Agropec. Bras. 47, 1007-1014 (In Portuguese, with English abstract).

Caires, E.F., Chueiri, W.A., Madruga, E.F., Figueiredo, A., 1998. Changes in soil chemical characteristics by surface application of lime and gypsum and soybean response in no-tillage system. (In Portuguese, with English abstract.). R. Bras. Ci. Solo 22, 27-34.

Caires, E.F., Fonseca, A.F., Mendes, J., Chueiri, W.A., Madruga, E.F., 1999. Corn, wheat and soybean yields as a function of the changes in soil chemical characteristics due to surface application of lime and gypsum under a no-tillage system. R. Bras. Ci. Solo 315-327 (In Portuguese, with English abstract)

Caires, E.F., Banzatto, D.A., Fonseca, A.F., 2000. Surface application of lime under a no-tillage system. R. Bras. Ci. Solo 24, 161-169 (In Portuguese, with English abstract).

Caires, E.F., Barth, G., Garbuio, F.J., Kusman, M.T., 2002. Influence of surface lime application in a no-tillage system on soil acidity, corn root growth and nutrition. R. Bras. Ci. Solo 26, 1011-1022 (In Portuguese, with English abstract).

Caires, E.F., Alleoni, L.R.F., Cambri, M.A., Barth, G., 2005. Surface application of lime for crop grain production under a no-till system. Agron. J. 97, 791-798.

Caires, E.F., Barth, G., Garbuio, F.J., 2006. Lime application in the establishment of a no-till system for grain crop production in Southern Brazil. Soil Till. Res. 89, $3-12$.

Caires, E.F., Garbuio, F.J., Churka, S., Barth, G., Corrêa, J.C.L., 2008. Effects of soil acidity amelioration by surface liming on no-till corn, soybean, and wheat root growth and yield. Eur. J. Agron. 28, 57-64.

Caires, E.F., Haliski, A., Bini, A.R., Scharr, D.A., 2015. Surface liming and nitrogen fertilization for crop grain production under no-till management in Brazil. Eur. J. Agron. 66, 41-53.

Calegari, A., Tiecher, T., Hargrove, W.L., Ralisch, R., Tessier, D., Tourdonnet, S. Guimarães, M.F., Santos, D.R., 2013. Long-term effect of different soil management systems and Winter crops on soil acidity and vertical distribution of nutrients in a Brazilian Oxisol. Soil Till. Res. 133, 32-39.

Cantarella, H., van Raij, B., Camargo, C.E.O., 1997. Cereals. In: van Raij, B., Cantarella, H., Quaggio, J.A. (Eds.), Recommendations for Fertilization and Liming the State of São Paulo. Agronomic Institute Campinas, Brazil (In Portuguese).

Carvalho, M.A.C., Yamashita, O.M., Roque, C.G., Noetzold, R., 2011. Rice yield in the crop-livestock integration using low herbicide doses. Bragantia 70, 33-39 (In Portuguese, with English abstract).

Castro, G.S.A., Crusciol, C.A.C., Menegale, M.L.C., 2012. Lyme and silicate surface application and water-soluble cation availability in anual crops and Brachiaria. R. Ci. Agron. 43, 740-748 (In Portuguese, with English abstract).

Castro, G.S.A., Crusciol, C.A.C., Calonego, J.C., Rosolem, C.A., 2015. Management impacts on soil organic matter of tropical soils. Vadose Zone J. 14, 1-8.

Cavalieri, K.M.V., Silva, A.P., Tormena, C.A., Leão, T.P., Dexter, A.R., Hakansson, I., 2009. Long-term effects of no-tillage on dynamic soil physical propertiesin a Rhodic Ferrasol in Paranã, Brazil. Soil Till. Res. 103, 158-164.

Cavallini, M.C., Andreotti, M., Oliveira, L.L., Pariz, C.M., 2010. Relationships between yield of Brachiaria brizantha and physical properties of a savannah oxisol. R. Bras. Ci. Solo 34, 1007-1015 (In Portuguese, with English abstract).

Conyers, M.K., Uren, N.C., Helyar, K.R., 1995. Causes of changes in pH in acidic mineral soils. Soil Biol. Biochem. 27, 1383-1392.

Conyers, M.K., Heenan, D.P., McGhie, W.J., Poile, G.P., 2003. Amelioration of acidity with time by limestone under contrasting tillage. Soil Till. Res. 72, 85-94.

Costa, S.E.V.G.A., Souza, E.D., Anghinoni, I., Flores, J.P.C., Andriguetti, M.H., 2009. Potassium and root distribution in soil and corn growth in long-term soil management and fertilization systems. R. Bras. Ci. Solo 33, 1291-1301 (In Portuguese, with English abstract)

Crusciol, C.A.C., Garcia, R.A., Castro, G.S.A., Rosolem, C.A., 2011. Nitrate role in basic cation leaching under no-till. R. Bras. Ci. Solo 35, 1975-1984.

Crusciol, C.A.C., Nascente, A.S., Mateus, G.P., Pariz, C.M., Martins, P.O., Borghi, E., 2014. Intercropping soybean and palisade grass for enhanced land use efficiency and revenue in a no till system. Eur. J. Agron. 58, 53-62.

Ferreira, A.C.B., Araújo, G.A.A., Pereira, P.R.G., Cardoso, A.A., 2001. Corn crop characteristics under nitrogen, molybdenum and zinc fertilization. Sci. Agric. 58, 131-138 (In Portuguese, with English abstract).

Franchini, J.C., Hoffmann-Campo, C.B., Torres, E., Miyazawa, M., Pavan, A., 2003. Organic composition of green manure during growth and its effect on cation mobilization in an acid Oxisol. Comm. Soil Sci. Plant Anal. 34, 2045-2058.

Gonçalves, J.R.P., Moreira, A., Büll, L.T., Crusciol, C.A.C., Villas Boas, R.L., 2011. Granulometric fractions and lime rates in conventional and no-tillage system. Acta. Sci. Agron. 33, 369-375 (In Portuguese, with English abstract).

Joris, H.A.W., Caires, E.F., Bini, A.R., Scharr, D.A., Haliski, A., 2013. Effects of soil acidity and water stress on corn and soybean performance under a no-till system. Plant Soil 365, 409-424.

Kaminski, J., Gatiboni, L.C., Rheinheimer, D.S., Martins, J.R., Santos, E.J.S., Tissot, C.A. 2002. Estimation of potential soil acidity and its role in the lime demand calculation. R. Bras. Ci. Solo 26, 1107-1113.

Limousin, G., Tessier, D., 2007. Effects of no-tillage on chemical gradients and topsoil acidification. Soil Till. Res. 92, 167-174.

Loss, A., Pereira, M.G., Giácomo, S.G., Perin, A., Anjos, L.H.C., 2011. Aggregation, carbon and nitrogen in soil aggregates under no-tillage with crop-livestock integration. Pesq. Agropec. Bras. 46, 1269-1276 (In Portuguese, with English abstract).

Magalhães, P.C., Jones, R., 1990. Assimilate enhancement on plant growth rate and final weight of corn kernels. Pesq. Agropec. Bras. 25, 1747-1754 (In Portuguese, with English abstract). 
Malavolta, E., Vitti, G.C., Oliveira, S.A., 1997. Evaluation of Plant Nutrition: Principles and Applications. Potafós, Piracicaba (201 pp. in Portuguese).

Mateus, G.P., Crusciol, C.A.C., Borghi, E., Pariz, C.M., Costa, C., Silveira, J.P.F., 2011. Nitrogen fertilization on sorghum intercropped with grass in a no-tillage system. Pesq. Agropec. Bras. 46, 1161-1169 (In Portuguese, with English abstract).

Mello, J.C.A., Villas Boas, R.L., Lima, E.V., Crusciol, C.A.C., Büll, L.T., 2003. Changes of chemical soil characteristics due to doses and particle sizes of limestone in notillage and conventional systems. R. Bras. Ci. Solo 27, 553-561 (In Portuguese, with English abstract).

Miyazawa, M., Pavan, M.A., Franchini, J.C., 2002. Evaluation of plant residues on the mobility os surface applied lime. Braz. Arch. Biol. Technol. 45, 251-256.

Moreira, S.G., Kiehl, J.C., Prochnow, L.I., Pauletti, V., 2001. Liming under no-tillage and effects on soil acidity, soil nutrient availability and corn and soybean yield. R. Bras. Ci. Solo 25, 71-81 (In Portuguese, with English abstract).

Murphy, J., Riley, J.P., 1962. A modified single solution method for the determination of phosphate in natural waters. Anal. Chim. Acta 27, 31-36.

Nye, P.H., 1981. Change of pH across the rhizosphere induced by roots. Plant Soil 61, 7-26.

Oliveira, E.L., Pavan, M.A., 1996. Control of soil acidity in no-tillage system for soybean production. Soil Till. Res. 38, 47-57.

Pöttker, D., 1998. Lime application for a crop rotation under no-tillage. R. Bras. Ci. Solo 22, 675-684 (In Portuguese, with English abstract).

Parfitt, R.L., 1978. Anion adsorption by soils and soil materials. Adv. Agron. 30, 1-50.

Pavinato, P.S., 2008. Effects of organic compounds produced by plants on soil nutrient availability. R. Bras. Ci. Solo 32, 911-920 (In Portuguese, with English abstract).

Rheinheimer, D.S., Santos, E.J.S., Kaminski, J., Bortoluzzi, E.C., Gatiboni, L.C., 2000. Changes in acid soil properties by superficial and incorporated liming on natural pasture. R. Bras. Ci. Solo 24, 797-805 (In Portuguese, with English abstract).

Rousk, J., Brookes, P.C., Bååth, E., 2009. Contrasting soil pH effects on fungal and bacterial growth suggest functional redundancy in carbon mineralization. Appl. Environ. Microbiol. 75, 1589-1596.

Salton, J.C., Mielniczuk, J., Bayer, C., Boeni, M., Conceição, P.C., Fabrício, A.C., Macedo M.C.M., Broch, D.L., 2008. oil aggregation and aggregate stability under croppasture systems in Mato Grosso do Sul state, Brazil. (In Portuguese, with English abstract). R. Bras. Ci. Solo 21, 2008.
Silva, C.A., Vale, F.R., 2000. Nitrate availability in brazilian soils under effect of liming and sources and amounts of nitrogen. Pesq. Agropec. Bras. 35, 2461-2471 (In Portuguese, with English abstract).

Soratto, R.P., Crusciol, C.A.C., 2008. Chemical soil attributes as affected by lime and phosphogypsum surface application in a recently established no-tillage system. R. Bras. Ci. Solo 32, 675-688 (In Portuguese, with English abstract).

Unicamp, 2012. Climate of municipalities of State of São Paulo: Botucatu. (In Portuguese) Available from http://www.cpa.unicamp.br/outras-informacoes/ clima_muni_086.html (accessed 10.07.12).

van Raij, B., Quaggio, J.A.V., Silva, N.M., 1986. Extraction of phosphorus, potassium, calcium and magnesium from soils by ion-exchange resin procedure. Commun. Soil Sci. Plant Anal. 17, 547-566.

van Raij, B., Cantarela, H., Quaggio, J.A., Furlani, A.M.C., 1997. Recommendations for Fertilization and Liming the State of São Paulo, Second ed. Agronomic Institute, Campinas, Brazil (in Portuguese).

van Hees, P.A.W., Lundström, U.S., Giesler, R., 2000. Low molecular weight acids and their Al complexes in soil solution: composition, distribution and seasonal variation in three podzolized soils. Geoderma 94, 173-200.

van Raij, B., Andrade, J.C., Cantarella, H., Quaggio, J.A., 2001. Chemical analysis for fertility evaluation of tropical soils. (in Portuguese). Agronomic Institute, São Paulo, Brazil.

Walkley, A., Black, I.A., 1934. An examination of the Degtjareff method for determining soil organic matter and a proposed modifi cation of the chromic acid titration method. Soil Sci. 37, 29-38.

Weber, M.A., Mielniczuk, J., 2009. Soil nitrogen stock and availability in a long-term experiment. R. Bras. Ci. Solo 33, 429-437 (In Portuguese, with English abstract).

Wenzl, P., Patiño, G.M., Chaves, A.L., Mayer, J.E., Rao, I.M., 2001. The high level of aluminum resistance in signalgrass is not associated with known mechanisms of external aluminum detoxification in root apices. Plant Physiol. 125, 1473-1484.

Yuan, T.L., 1959. Determination of exchangeable hydrogen in soils by a titration method. Soil Sci. 88, 164-167.

Zech, W., Senesi, N., Guggenberger, G., Kaiser, K., Lehmann, J., Miano, T.M., Miltner, A., Schroth, G., 1997. Factors controlling humification and mineralization of soil organic matter in the tropics. Geoderma 79, 117-161. 